\title{
Museum and center for contemporary art: design principles and functional features
}

\author{
Elza Bashirova ${ }^{1 *[0000-0002-0346-1713]}$, Elena Denisenko ${ }^{1[0000-0002-3155-2153]}$, Kamilla Akhmetova ${ }^{1}$, \\ and Vilnur Kadirov ${ }^{1}$ \\ ${ }^{1}$ Kazan State University of Architecture and Engineering, 420043 Kazan, Russia
}

\begin{abstract}
The article discusses the topical issue of the establishment of museum and center for contemporary art. The objective of the research is to analyze the historical background of contemporary art museums; to review the world design practice of them according to urban planning, functional, architectural and expositional criteria; to reveal functional features' trends and to identify the design principles of an advanced center for contemporary art. We collected more than 45 leading examples to compile a matrix using classification and analysis methods. As a result, we reached the museums' functional features: administrative, exhibition, educational, recreational are fixed functions; storage and research functions are optional; cultural and entertainment are particularly additional functions. At first, art museums and centers are focused on adaption to visitors and intersection with them, secondly, on the exhibit. To sum up, we define the design principles of the ideal architectural model on the basis of urban planning, architectural, sociocultural and technological radicals. In conclusion, it is revealed that contemporary art centers have absorbed most of the historical functions of the museum and today are one of the developed types of the multifunctional architecture.
\end{abstract}

Keywords. Architecture, center for contemporary art, museum, contemporary art, design principles, functional features.

\section{Introduction}

Contemporary art, that was formed by the end of the Second World War and has been changing its appearance up to the present time, has become an integral part of the social and cultural life of a person. Modern art can be found in architecture, design, cinema, music, and it gives rise to new creative artists who rethink art by forming new spaces for interaction with it. Contemporary art becomes cramped within the framework of a classically established museum, which utilitarian functions were the study and preservation of natural history monuments. Solomon Guggenheim Museum in New York by Frank Lloyd Wright (1959) was one of the first contemporary art museums that responded to the new trends. In the XX century, museum institutions began its transformation to a new architectural typology of the center for contemporary art by preserving the existing museum functions and creating a new integrated socially orientated multifunctional system. The striking example of this typology is Centre Georges Pompidou in Paris by Renzo Piano and Richard Rogers (1977).

\footnotetext{
*Corresponding author: bashirova.arch@gmail.com
} 
In the XXI century, museums' requirements are evolving, they are becoming more than cultural and educational institutions. In accordance with the new requirements the museums' objective is not just to exhibit and storage contemporary art, but to offer the visitor a range of leisure and entertainment activities, transforming a contemporary art museum into a cultural center. The design concept for a contemporary art center is linked to contemporary art itself.

The tendency of historical changes in modern art museum raises relevant question of the existence of this typology today and its further development in the future.

The object of the current study is architecture of museum and center for contemporary art.

The purpose of the study is to form design principles and identify functional features' trends of museums and centers for contemporary art.

The objectives of the study were the following:

- to analyze the prerequisites for the formation of the first museums and centers for contemporary art;

- to analyze and identify the functional features of museums and centers for contemporary art;

- to distinguish between the concepts of a museum and a center for contemporary art, to determine the differences between typologies;

- to formulate the design principles of museums and centers for contemporary art.

The relevant issue is designing museums in the historical context: developing a method for assessing the compatibility of a new building with the characteristics of the historic building. This issue has been studied by many researchers. For example, a number of researchers have raised the following complex issues: about the form and morphology, types of contextual design and their strategy, and also derived the criteria used as a basis for the museum's design practice $[1,2]$. The architectural evaluation method of new exterior extensions to historical buildings was considered by Hülya Yüceer in the article [3]. The research is based on architectural analysis, which includes environmental relations, relations between the building and the site, and also the facade composition combining historical and modern parts. "Analysis results showed that the value of the historic building should first clearly be identified and a new addition should bear the identity of its own period» [3]. Modern trends in the formation of exhibitions are analyzed by Tatiana Burova in her article [4]. The analysis of the spatial and object organization allows us to identify general directions and signs of the formation of exhibition elements for the consumption of «visual information», and the principle of «exhibition scenario» helps us to form the conceptual space of the exhibition [4]. In the context of our study, articles allow us to form a context-medium principle in the design of the museum and contemporary art center within the surrounding architecture $[5,6]$.

Due to the growing role of the museum in urban development and the growing challenges of city museums, Kali Tzortzi's study of the emergence of the model of the urbanized museum is important. The author examines the spatial and visual links between the museum building and the surrounding urban landscape, which can be linked to Foucault's concept of the modern episteme [7]. In the article on The Future of French Museums 2030, the authors derived future museum scenarios whose methods are applicable to the museums all over the world [8]. Studying the concept of forming a museum is also very important. Based on the study of the museum development history, the main principles of the museum can be identified [9]. The relationship between technology and art is much closer than is commonly believed. The articles raise issues of interaction between different structures and the organization of spaces for collaboration between artists, technicians in the creation of interactive art, three-dimensional technologies [10, 11]. Roberto Leonarduzzi's article examines the use of modern technology to authenticate works of art, which in turn helps to analyze and identify the databases of the art object and its creators [12]. The issues of lighting technology in exhibition spaces are addressed by Khaled A. Al-Sallal. The author provides a comprehensive research process on the characteristics of daylight in relation to museum lighting, taking into account the risk of damage to the exhibits and visual comfort [13]. The use of technology in the creation of a virtual museum and interaction with the exhibition is a 
relevant issue. The application of such technologies is observed in the exhibition area of the museum: digital content can be enriched at the request of museum visitors using mobile devices [14]. When a museum is unavailable, ICT technology and digitization technology have found their way into the new digital space of the virtual museum $[15,16]$. A technological database can be used to collect information on the understanding of museum visitors' behavior, and to regulate the museum in order to increase the cultural engagement of new visitors by applying clustering and forecasting methods to the collected data [17, 18].

Research into the social aspect of museum practice is relevant. Yaohua Su's article explores the reviews of visitors to iconic museums, namely negative ones, in Internet resources. Based on the feedback, the author concludes that the purpose of visiting museums and art centers is to receive education, so the museum's design should take into account the same educational zone area as the area of the entertainment zone [19]. The shaping of the museum and contemporary art center of the future is discussed in an article by Sandra Kemp. The author talks about the influence of museums as a catalyst for educational and cultural development and considers the museum as a space for imagining new types of social institutions [20]. An important issue is the study of the length of stay and the level of saturation of visitors. The author concludes that the route in the exhibition area should be regulated in order to limit the time the viewer stays in the exhibit area, and additional human rest areas for emotional and mental relaxation should be introduced [21]. The influence of contemporary art in psychotherapy work is a relevant topic. Participants in art psychotherapy, through works of contemporary art, discuss personal issues and assimilate the cultural world to get to know different aspects of themselves. In museums and contemporary art centers, this space is called a therapeutic space, where artists and participants come together and help each other to achieve a greater awareness of their psychological state $[22,23]$.

\section{Materials and methods}

This study reveals the functional features and design principles of museum and center for contemporary art, it requires the analysis of world design practice of the typology among XX-XXI century. We collected more than 45 leading examples and used following methods to compile a matrix «The functional features tendencies of museums and centers for contemporary art» (Fig. 1):

1. Modeling method: recreation of the $3 \mathrm{D}$ form of the building to reveal the spatial organization of centers and museums for contemporary art.

2. Method of analysis: the objects were divided into its constituent functional parts.

3. Method of synthesis: systematization analytical data on museums and centers for contemporary art in a matrix to study their characteristics.

4. Comparison method: establishing the similarities and differences between art centers and museums of contemporary art.

5. Method of classification: combining criteria and features of museums and centers for contemporary art into certain groups, types in order to establish connections between the objects.

6. Historical method: explores the process of occurrence, becoming and development of contemporary art museums to determine the architectural trends.

We used following methods for forming museum and center for contemporary art design principles:

1. Analogy method: review international analogues of the typology.

2. Method of deduction: analyze the common features of museums and centers for contemporary art, find out particular results - the design principles.

3. Method of summarization: identify common properties, connections, patterns in objects and generalize these criteria into unified principles. 

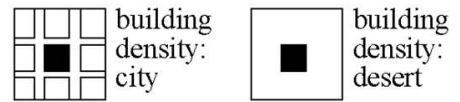
desert
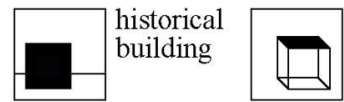
greenary:
part of the
building
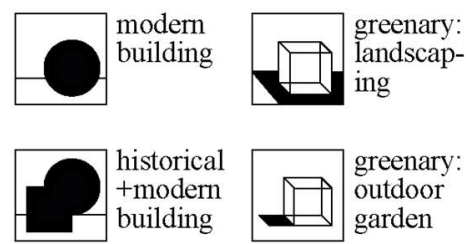

USA

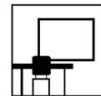

education function
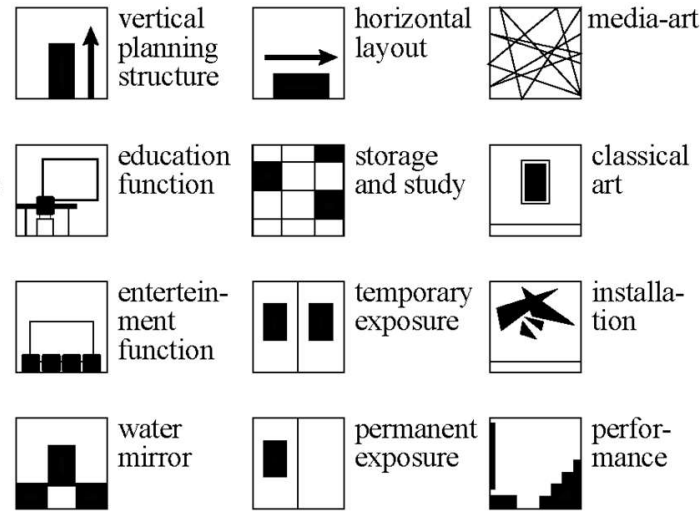

a.

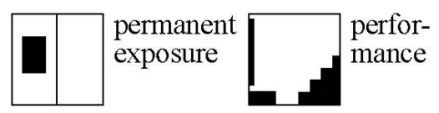

Europe
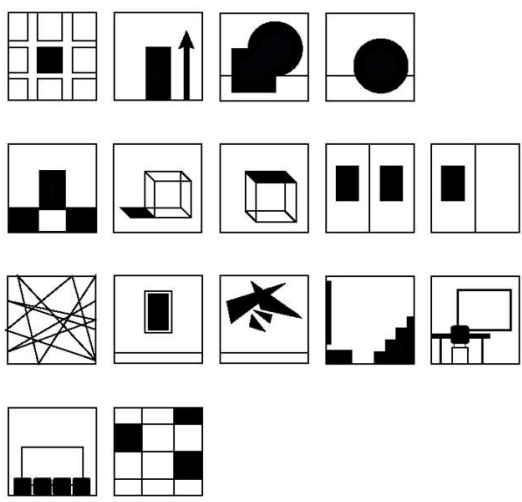

Asia
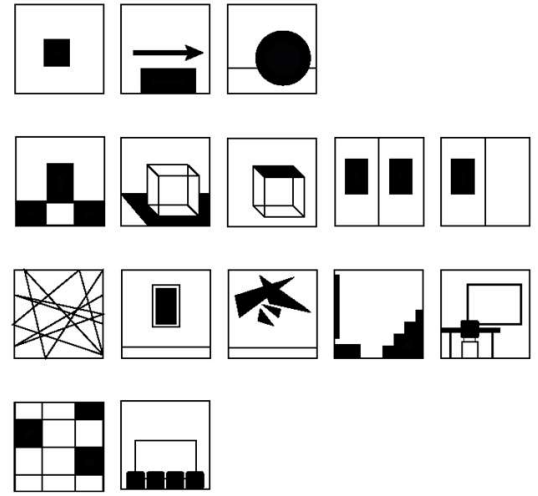

d.
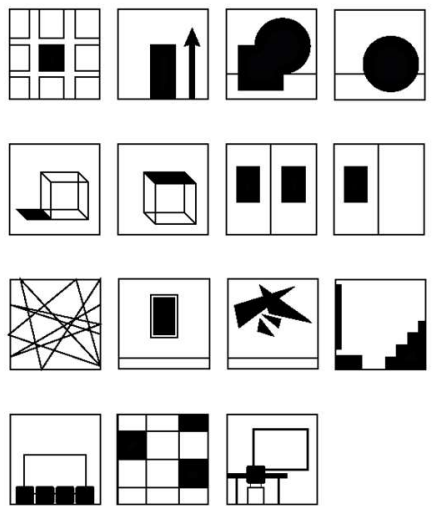

b.

Russia
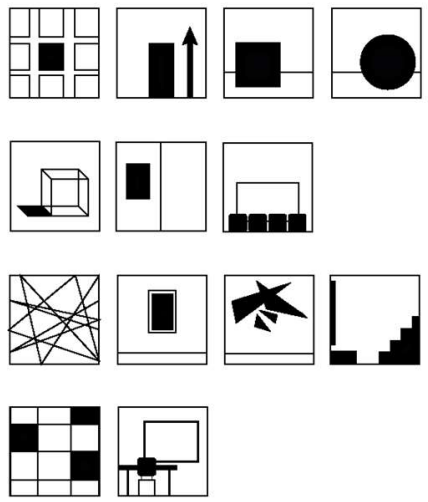

Fig. 1. a. The functional features tendencies of museums and centers for contemporary art; $b$. The tendency of functional features of museum and center for contemporary art in the USA; $c$. The tendency of functional features of museum and center for contemporary art in Europe; d. The tendency of functional features of museum and center for contemporary art in Asia; e. The tendency of functional features of museum and center for contemporary art in Russia.

The research materials were photographs, drawings, layouts, theoretical aspects through the literature: articles, monographs. 


\subsection{Feature classification in the matrix}

In this paper we consider design experience, organization and constructions of American, European, Asian and Russian museums and contemporary art centers and identify their functional features. We collected more than 45 examples in one matrix (Fig. 1a) and classified them according to the following criteria:

1. Urban development situation.

2. Functional program.

3. Architectural solution.

4. Exposition solutions.

Urban development situation determines the location of the center/museum in the city (historical/modern); the existence of the nearest water bodies, rivers, parks, squares - green massif; the existence of the parking and its character; building density.

The geographical features impose a number of limitations and determine the volumespatial structure, the architectural and the master planning solutions.

Type of building is divided into the following criteria: determination of the type of building (historical/modern/mixed) and the type of planning structure (linear, circular, square).

Functional program is divided into the following criteria: educational (workshops, private studios, lecture hall, library), related (shop, cafe, interactive area, lounge area, forum), cultural and entertainment (cinema, stage, theater), administrative (offices, conference rooms, recording rooms, rent), storage and study (collection point for exhibits, fund storage) and exhibition halls, which are discussed in detail in a separate paragraph. This classification helps to determine the full list of the functional program of the center and to answer the question: is there a difference between functional programs of centers and museums for contemporary art.

The entertainment function especially analyzing in detail the presence of synthetic art functions: theater, performance, concert, cinema, dance. This attribute brings the center/ museum for contemporary art into a new typology, going beyond the usual exhibition center.

Architectural approach determines trends in the appearance of the building: used facade materials, types of natural lighting, etc.

Exposition approach is divided into the following criteria: modes of exposition (temporary/permanent) and types of exposition (private/ center/combined). The criteria influence the formation of the volumetric-spatial structure, on the concept of the center itself, its architecture and brand.

The planning structure of the exhibition zones: this criterion characterizes the planning structure of contemporary art center exposure sites (temporary/permanent/free/strict/ multifunction/mixed). This criterion helps to determine the most profitable and convenient model of the exhibition, taking into account the trends in the storage design and in building communication organizations.

Exposure forms defines the nature of the type of exhibited art (paid/free exhibition, modern classical art, contemporary art today, mixed). This criterion helps to form the volume of the storage fund area, the parameters in the design of galleries (height, the exposure method, the area, types of exhibits, the presence of natural light).

\section{Results}

\subsection{The emergence of museums and centers for contemporary art: historical background}

In this paper we conduct the historical research based on the museum design practice since the 1950s. The increasing popularity of the museum construction and design was dictated by 
the «museum boom». The most striking tendencies of the new approach in the design of the contemporary art museum were:

The tendency of «ideal space» - the construction of the museum creates a universal exposition space, forming a single large pavilion. For example, New National Gallery in Berlin (by Ludwig Mies van der Rohe, 1968) and Sainsbury Centre for Visual Arts at the University of East Anglia (by Norman Foster, 1978).

The tendency of uniting museum and other institutions in the center of cultural activity and artistic production. For example, Centre Georges Pompidou in Paris (by Renzo Piano, 1977) and The House of Culture in Stockholm (by Ricardo Optis, 1971).

The tendency of the museum as a tool for urban renewal. For example, the Museum Quarter (by Ortner \& Ortner, 2001), which transformed the former imperial stable complex into an ensemble of museums, exhibition halls and cultural centers. This trend has spread widely in the Middle East and in China.

The tendency of the museum as an object of cultural attraction, forming the resent increase of tourism. For example, the pioneer of the trend is The Guggenheim Museum Bilbao, Italy (by Frank Gehry, 1997). The followers are: Tate Modern in London, Great Britain (by Herzog \& de Meuron, 2000), MAXXI Museum in Rome, Italy (by Zaha Hadid Architects, 2009) and Saadiyat island in Abu-Dabi, United Arab Emirates with Guggenheim Abu Dhabi Museum (by Frank Gehry, under construction) and Louvre Abu Dhabi (by Jean Nouvel, 2017).

\section{Discussion}

\subsection{The functional features tendencies of museums and centers for contemporary art}

There are a number of trends, common factors that identify the present center for contemporary art, but it is difficult to determine the centers' precise functional design regulations. However, several functional features tendencies are defined by the matrix' analysis (Fig. 1). The center/museum of contemporary art is located mostly in the city centers in the USA, Europe (V\&A Museum in London (by AL_A, 2017); MOMA in New York (by Diller Scofidio + Renfro, 2019)); but Asian centers/museums are mostly out of town, located in desolate areas (Shuyang Art Gallery in China (by UAD, 2013). The architectural planning structure of USA and European museums shows that majority of objects are vertically upwards (Rosenthal Center for Contemporary Art in Cincinnati, USA (by Zaha Hadid Architects, 2003) and Contemporary Art Center - FRAC in Marseille, France (by Kengo Kuma, 2013)), on the contrary - horizontal layout - develops longitudinally in Asia (Chongqing Tiandi Art Museum in China (by Shenzhen Huahui Design, 2017). In the same place, the presence of an entertainment functions such as scenes, cinemas, performances, theater, is minimal, while in USA, in almost every center there are all these functions. It is worth noting, there are also a number of uniting tendencies on the center's territory: a water mirror, green plantings, domestic courtyards, sculpture gardens, exploited terraces - are found in the newest buildings quite often (Exhibition Center of Shimao in Shenzhen-Hong Kong International Center in China (by SHUISHI, 2019) and The Nelson-Atkins Museum of Art in Kansas City, USA (by Steven Holl, 2007)). In terms of functional features - the presence of a storage area, permanent and temporary exposure, small workshops and classes, forum, cafes and shop are in almost every contemporary art center. Moreover, the use of not only lateral ribbon lighting, but also overhead natural lighting in galleries and exhibitions is the standard design practice, particularly found in centers, exponential whose exhibited objects are related to contemporary art of the present day (Institute for Contemporary Art at VCU in Richmond, USA (by Steven Holl, 2018)). 


\subsection{Design principles of museums and centers for contemporary art}

The matrix analysis of more than 45 historical and modern museums for contemporary art gives us the general understanding of the functional features of buildings, so that we define the principles by which they were designed. The design principles are divided into 4 main radicals: urban planning, architectural, socio-cultural and technological. These principles can be applied to all public buildings, but a number of criteria apply exclusively to under study typology.

\subsubsection{Urban planning radical}

The principle of interaction with the environment determines how the object fits into the surrounding area.

a. Contextual design is a design principle that takes into account the environmental characteristics of the development area, which determines the requirements for the building (space-planning structure, architectural appearance, landscaping). For example, Museum of Contemporary Art B\&E Goulandris (by Vikelas Architects, 2019) (Fig. 2).

b. Out-of-context design is a design principle which determines the object as a strongly contrast element in its environment, like playing on the contrast of old and new. For example, MUMOK in Vienna as a part of the Museum Quarter (by Ortner \& Ortner, 2001) (Fig. 2).

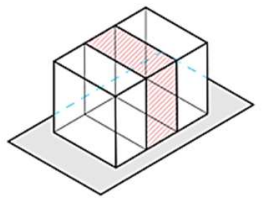

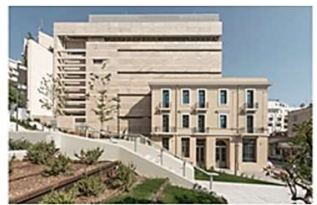

a.

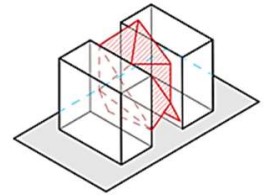

b.

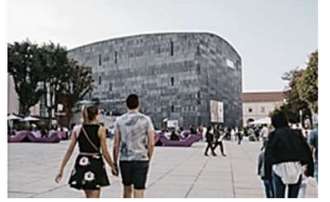

Fig. 2. a. Contextual design illustration \& Museum of Contemporary Art B\&E Goulandris (by Vikelas Architects, 2019). Photo from the site: https://www.vikelas.gr/work/museum-of-contemporary-art-b-egoulandris.

b. Out-of-context design illustration \& MUMOK in Vienna as a part of the Museum Quarter (by Ortner \& Ortner, 2001). Photo from the site: https://www.mumok.at/de/zeiten-preise.

Urban principle is a principle, that takes into account the quality of the urban environment next to the object.

a. Infrastructural approach is an approach that determines the future museum design area based on the most favorable environment principle: taking into account the transport and infrastructural terrain. For example, Guardian Art Center in Beijing, China (by Buro Ole Scheeren, 2017) (Fig. 3).

b. Renaissance approach is an approach in which we choose the future museum design area so that the object contributes to the revival and development area's infrastructure. For example, MAXXI Museum in Rome, Italy (by Zaha Hadid Architects, 2009) (Fig. 3).

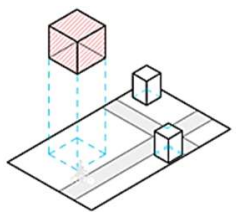

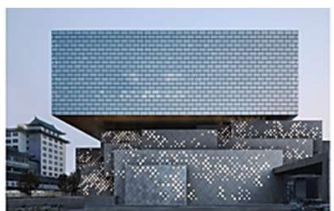

a.

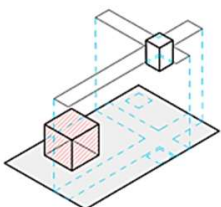

b.

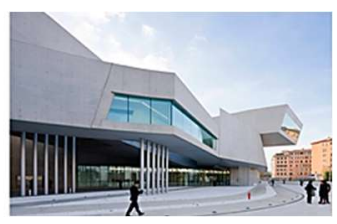

Fig. 3. a. Infrastructural approach illustration \& Guardian Art Center in Beijing, China (by Buro Ole Scheeren, 2017). Photo from the site: https://buro-os.com/projects/guardian-art-center. 
b. Renaissance approach illustration \& MAXXI Museum in Rome, Italy (by Zaha Hadid Architects, 2009). Photo from the site: https:/www.zaha-hadid.com/architecture/maxxi/.

The principle of site improvement governs the functional content of the site.

a. Social factor - environmental improvement through the creation of recreational areas: children's area, amphitheatre, interactive area. For example, the inner garden in the Museum Quarter (by Ortner \& Ortner, 2001) (Fig. 4).

b. The exposition factor - environmental improvement through the creation of art objects, street exhibitions and exhibition routes areas. For example, the famous sculptures by Louise Bourget, Jeff Koons located on the territory of The Guggenheim Museum Bilbao, Italy (by Frank Gehry, 1997) (Fig.4).

c. Environmental factor - environmental improvement through the green framework creation: planting, landscape design, water mirror. For example, MOMA in New York (by Diller Scofidio + Renfro, 2019) (Fig. 4) and The Oakland Museum in Oakland, California (by Kevin Roche, 1968).

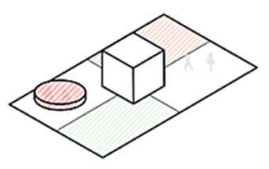

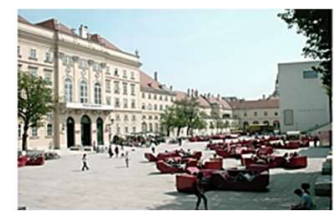

a.

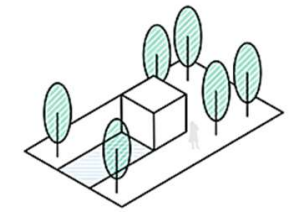

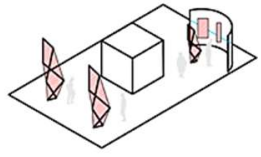

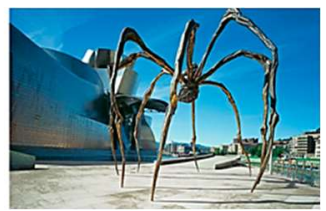

b.

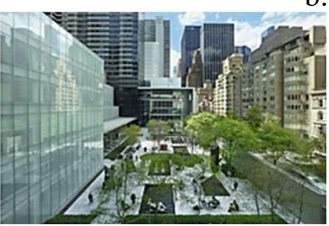

c.

Fig. 4. a. Social factor illustration \& Museum Quarter (by Ortner \& Ortner, 2001). Photo from the site: https://www.mumok.at/en/architecture. b. The exposition factor illustration \& «Mama» sculpture (by Louise Bourgeois, 1999). Photo from the site: https://www.guggenheim-bilbao.eus/en. c. Environmental factor illustration \& MOMA in New Yourk (by Diller Scofidio + Renfro, 2019). Photo from the site: https://www.moma.org/.

\subsubsection{Architectural radical}

The principle of architectural planning (structure) determines layouts, zoning and route of a center/museum visitor.

a. Enfilade type - a direct sequence of exhibition halls. For example, San Francisco Museum of Modern Art (by Mario Botta architect, 1995) (Fig. 5).

b. Closed type - an annular sequence of exhibition halls. For example, Solomon R. Guggenheim Museum (by Frank Lloyd Wright, 1959) (Fig. 5).

c. The pavilion type - the open space of the exhibition hall, transformable space for the exposition. For example, New National Gallery in Berlin (by Ludwig Mies van der Rohe, 1968) (Fig. 5).

d. Vertical structure - each floor of the center/museum is assigned to one specific function. For example, New Art Museum in New York (by SANAA, 2007) (Fig. 5).

e. Spatial penetration - one block of the center/museum penetrates another one, blocks' functions are mixed. For example, Künsthal is a museum in Rotterdam (by Rem Koolhaas, 1992) (Fig. 5). 
f. Spatial isolation - each block of the center/museum is autonomous, it has an entrance and an exit, and it is defined by one function. For example, Art Museum Bonn in Germany (by Axel Schultes, 1992) (Fig. 5).
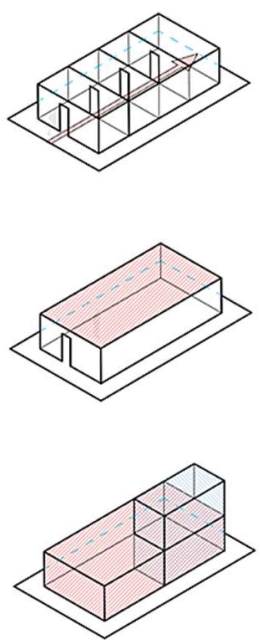

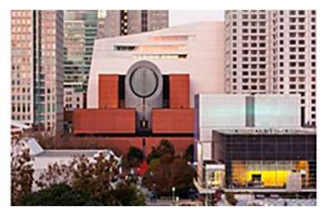

a.

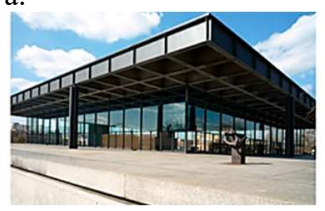

c.

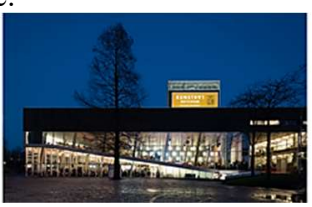

e.
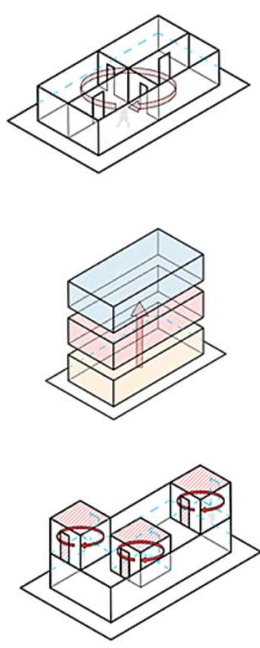

f. d.
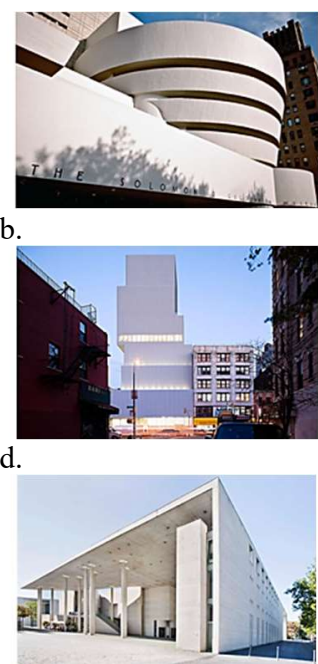

b.

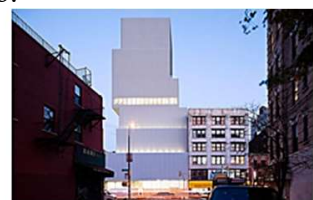

Fig. 5. a. Enfilade type illustration \& San Francisco Museum of Modern Art (by Mario Botta architect, 1995). Photo from the site: https://www.facebook.com/sfmoma. b. Closed type illustration \& Solomon R. Guggenheim Museum (by Frank Lloyd Wright, 1959). Photo from the site: https://www.guggenheim.org/. c. The pavilion type illustration \& New National Gallery in Berlin (by Ludwig Mies van der Rohe, 1968). Photo from the site: http://surl.li/pwgt. $d$. Vertical structure illustration \& New Art Museum in New York (by SANAA, 2007). Photographs: Iwan Baan. e. Spatial penetration illustration \& Künsthal is a museum in Rotterdam (by Rem Koolhaas, 1992). Photo from the site https://www.kunsthal.nl/.f. Spatial isolation illustration \& Art Museum Bonn in Germany (by Axel Schultes, 1994). Photo from the site https://www.kunstmuseum-bonn.de/architektur/.
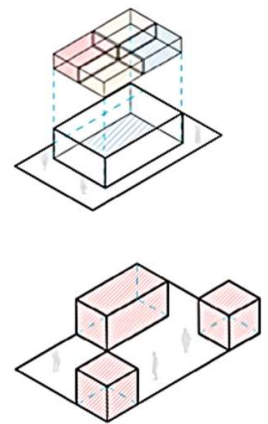

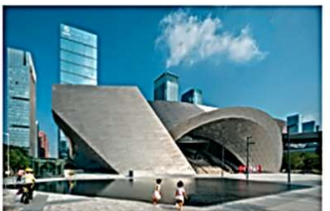

a.

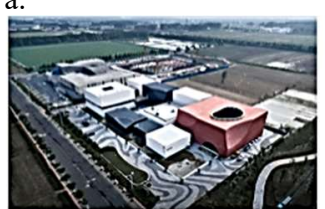

c.
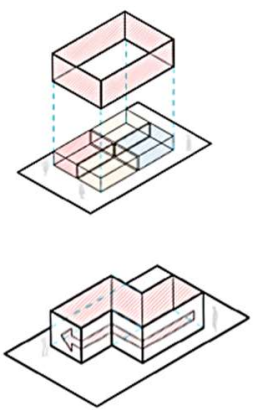

d.

b.
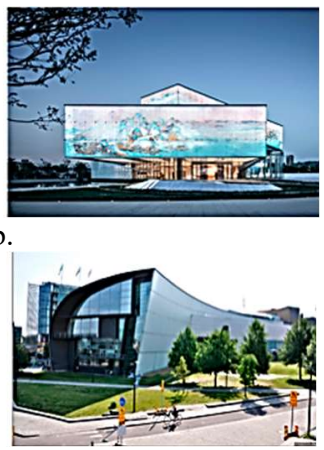

Fig. 6. a. The museum-exhibit method illustration \& Museum of Contemporary Art \& Planning Exhibition in Shenzhen, China (by Coop Himmelb(l)au, 2016). Photos: Duccio Malagamba; b. Ideal space method illustration \& Exhibition Center of Shimao in Shenzhen-Hong Kong International Center in China (by SHUISHI, 2019). Photo from the site: https://archello.com/project/exhibition-center-ofshimao; c. The ensemble method illustration \& Shuyang Art Gallery in China (by UAD, 2013). Photographs: Qiang Zhao; $d$. The spatial narrative method illustration \& Kiasma - Museum of Contemporary Art in Helsinki, Finland (by Steven Holl ,1998). Photo from the site: https://kiasma.fi/. 
The principle of shaping defines the concept of the external appearance/architecture of the center/museum.

a. The museum-exhibit method - the design of the museum goes from form to function. For example, Museum of Contemporary Art \& Planning Exhibition in Shenzhen, China (by Coop Himmelb(1)au, 2016) (Fig. 6).

b. Ideal space method - the internal exhibition space dictates the exterior appearance of the building. For example, Exhibition Center of Shimao in Shenzhen-Hong Kong International Center in China (by SHUISHI, 2019) (Fig. 6).

c. The ensemble method - is a cluster type of museum design, involving several museums in the same area. For example, Shuyang Art Gallery in China (by UAD, 2013) (Fig. 6).

d. The spatial narrative method is a method by which the museum's space transmits the exhibitions' ideas to the visitor through its architecture. For example, Kiasma - Museum of Contemporary Art in Helsinki, Finland (by Steven Holl ,1998) (Fig. 6).

\subsubsection{Sociocultural radical}

Social principle takes into account the influence of the human being on the functional organization of the center/museum.

a. Museum-play approach is based on a variety of entertainment functions. For example, Centre Georges Pompidou in Paris (by Renzo Piano and Richard Rogers, 1977) (Fig. 7).

b. Cultural and educational approach is primarily based on art exhibitions and on the educational function. For example, The Stedelijk Museum in Amsterdam, Netherlands (by Benthem Crouwel Architects, 2012) (Fig. 7).

c. Adaptive approach is aimed at a small special population group: for children, for people with disabilities. For example, The Louvre Haptic Gallery in Paris (1995) (Fig. 7).

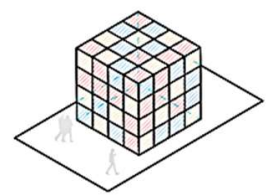

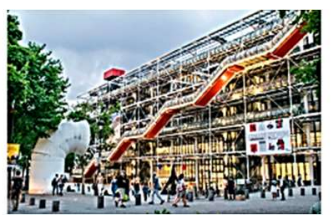

a.

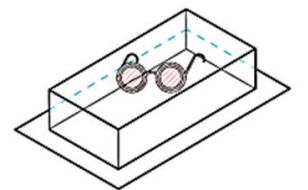

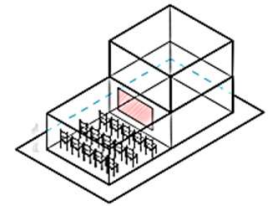

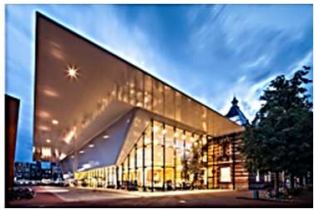

b.

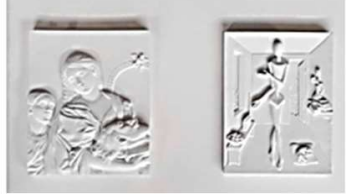

Fig. 7. a. Museum-play approach illustration \& Centre Georges Pompidou in Paris (by Renzo Piano and Richard Rogers, 1977). Photo from the site: https://www.centrepompidou.fr/fr/; b. Cultural and educational approach illustration \& The Stedelijk Museum in Amsterdam, Netherlands (by Benthem Crouwel Architects, 2012). Photo from the site: https://www.stedelijk.nl/en; c. Adaptive approach illustration \& The Louvre Haptic Gallery in Paris (1995).

Cultural principle determines the type of exhibition.

a. The principle of cultural globalism is an exposition of world-renowned contemporary art. For example, The Museum of Modern Art in New-York in USA (by Philip Johnson, 1936) (Fig. 8).

b. The principle of cultural locality is an exposition of contemporary art objects of local creativity. For example, Louisiana Museum of Modern Art in Denmark (by Wilhelm Wollert and Jorgen Bo, 1958) (Fig. 8). 

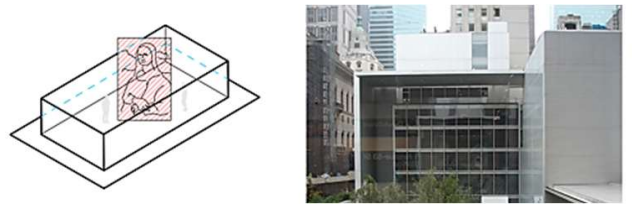

a.

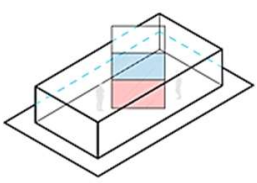

b.

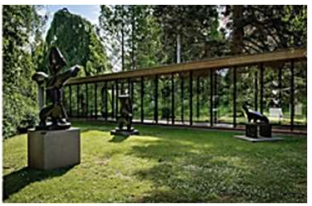

Fig. 8. a. The principle of cultural globalism illustration \& The Museum of Modern Art in New-York in USA (by Philip Johnson, 1936). Photo from the site https://www.moma.org/; b. The principle of cultural locality illustration \& Louisiana Museum of Modern Art in Denmark (by Wilhelm Wollert and Jorgen Bo, 1958). Photo from the site https://louisiana.dk/.

\subsubsection{Technological radical}

The principle of sustainable development governing the minimum environmental impact of the center/museum.

a. Energy Conservation - the use of alternative energy sources. For example, Institute for Contemporary Art at VCU in Richmond, the USA (by Steven Holl, 2018). The LEED Gold is heated and cooled by geothermal wells, gathering as much energy during the winter to heat the building as in the summer to cool the building (Fig. 9).

b. Green framework - the use of natural resources (environmental materials, green farms, operating roofs). For example, \& The Oakland Museum in Oakland, California (by Kevin Roche, 1968) (Fig. 9).

c. Materials - the use of ecological materials in building construction, interior and exterior.

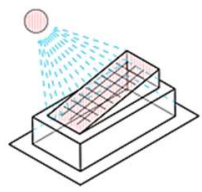

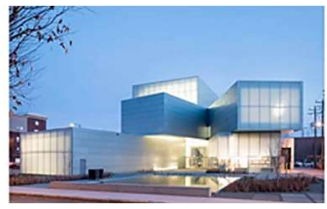

a.

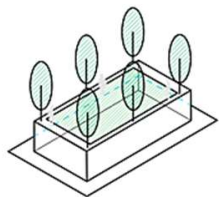

b.

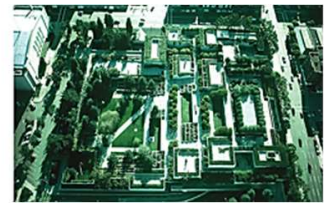

Fig. 9. a. Energy Conservation illustration \& Institute for Contemporary Art at VCU in Richmond, USA (by Steven Holl, 2018). Photographs: Iwan Baan; b. Green framework illustration \& The Oakland Museum in Oakland, California (by Kevin Roche, 1968). Photo from the site https://museumca.org/.

The principle of the use of modern technologies governs the obligatory use of modern technologies in expositions and exhibition spaces of the center/museum.

a. The principle of the foundation - the art (digital art) uses exhibition space not as a background to the exhibit, but the part of it. For example, EYE Netherlands Film Institute in Amsterdam (by Delugan Meissel Associated, 2012) (Fig. 10).

b. Database/digital technology - the exposition is determined by analyzing visitors' data. For example, Solomon R. Guggenheim Museum (by Frank Lloyd Wright, 1959) (Fig. 10).
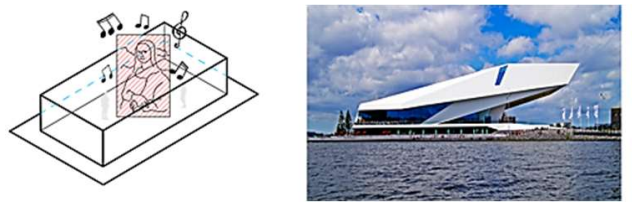

a.

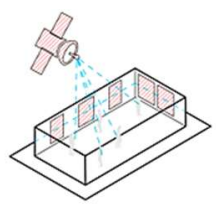

b.

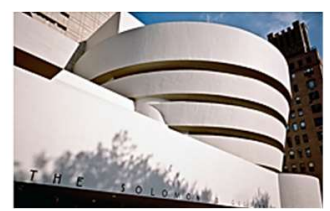

Fig. 10. a. The principle of the foundation illustration \& EYE Netherlands Film Institute in Amsterdam (by Delugan Meissel Associated, 2012). Photo from the site https:/www.eyefilm.nl/en; b. Database/digital technology illustration \& Solomon R. Guggenheim Museum (by Frank Lloyd Wright, 1959). Photo from the site https://www.guggenheim.org/. 


\section{Conclusion}

The first trends of a museum design for contemporary art were formed in the «museum boom» of the 1950s. Museums built at that period became prototypes for current contemporary art centers. We analyzed more than 45 examples of museums and centers for contemporary art, and determined that some functions of the center and the museum are similar: they both specialize in the display of art objects, in holding contemporary art exhibitions and events, in teaching and conducting master classes. The form of contemporary art changes, that leads to museum spatial modernization and to its functional expanding. The exhibition areas became multifunctional: containing equally art objects and creative areas for performances, digital installations and chamber theatres. The design regulations for a contemporary art center are rather vague, so we determine the design principles of centers based on functional analysis of buildings. There are 4 main radicals: Urban planning radical (The principle of interaction with the environment; Urban principle; The principle of site improvement); Architectural radical (The principle of architectural planning (structure); The principle of shaping); Sociocultural radical (Social principle; cultural principle); Technological radical (The principle of sustainable development; The principle of the use of modern technologies). Received design principles of contemporary art centers provide a basic understanding of this typology and can help in designing of other public buildings. This article was the first attempt to summarize the experience and comprehend the general, most striking and significant trends and phenomena of the center for contemporary art, which could be addressed within the framework of follow-up research.

\section{References}

1. B.I. Farahat, K.A. Osman. Toward a new vision to design a museum in historical places, HBRC Journal 14, 66-78 (2018). DOI: 10.1016/j.hbrcj.2016.01.004.

2. M.V. Dutsev. The architectural concept of universal arts Center 1. - Nizhniy Novgorod, 24 (2005) [in Russian].

3. H. Yüceer, B. İpekoğlu. An architectural assessment method for new exterior additions to historic buildings, Journal of Cultural Heritage 13, 419-425 (2012). DOI: 10.1016/j.culher.2011.12.002.

4. T.Y. Burova. Modern trends in the formation of expositions, Izvestiya KGASU 1 (43), 72-78 (2018).

5. M. Mixaila. Museum Side of the City - From the Theory to Inquiry, Procedia - Social and Behavioral Sciences 149, 570-574 (2014). DOI: 10.1016/j.sbspro.2014.08.212.

6. Kh.M. Tokaeva. Museu $m$ as a new element of cognition of the world, Science, education and experimental design 10, 181-185 (2020). DOI: 10.24411/9999-034A-2020-10036.

7. K. Tzortzi. The museum and the city: Towards a new architectural and musicological model for the museum?, City, Culture and Society 6, 109-115 (2015). DOI: 10.1016/j.ccs.2015.07.005.

8. B. Pauget, J.M. Tobelem, J.P. Bootz. The future of French museums in 2030, Technological Forecasting and Social Change 162, 120384 (2021). DOI: 10.1016/j.techfore.2020.120384.

9. B. Günay. Museum Concept from Past to Present and Importance of Museums as Centers of Art Education, Procedia - Social and Behavioral Sciences 55, 1250-1258 (2012). DOI: 10.1016/j.sbspro.2012.09.622.

10. J. Myounghoon, R. Fiebrink, E.A. Edmonds, D. Herath. From rituals to magic: Interactive art and HCI of the past, present, and future, International Journal of HumanComputer Studies 131, 108-119 (2019). DOI: 10.1016/j.ijhcs.2019.06.005. 
11. C. Balletti, M. Ballarin, F. Guerra. 3D printing: State of the art and future perspectives, Journal of Cultural Heritage 26, 172-182 (2017). DOI: 10.1016/j.culher.2017.02.010.

12. R. Leonarduzzi, H. Liu, Y. Wang. Scattering transform and sparse linear classifiers for art authentication, Signal Processing 150, 11-19 (2018). DOI: 10.1016/j.sigpro.2018.03.012.

13. K.A. Al-Sallal, A.R. AbouElhamd, M.B. Dalmouk. UAE heritage buildings converted into museums: Evaluation of daylighting effectiveness and potential risks on artifacts and visual comfort, Energy and Buildings 176, 333-359 (2018). DOI: 10.1016/j.enbuild.2018.06.067.

14. G. Ioannakis, L. Bampis, A. Koutsoudis. Exploiting artificial intelligence for digitally enriched museum visits, Journal of Cultural Heritage 42, 171-180 (2020). DOI: 10.1016/j.culher.2019.07.019.

15. P. Gutowski, Z. Kłos-Adamkiewicz. Development of e-service virtual museum tours in Poland during the SARS-CoV-2 pandemic, Procedia Computer Science 176, 2375-2383 (2020). DOI: 10.1016/j.procs.2020.09.303.

16. N. Alshawaaf, S.H. Lee. Business model innovation through digitisation in social purpose organisations: A comparative analysis of Tate Modern and Pompidou Centre, Journal of Business Research 125, 597-608 (2021). DOI: 10.1016/j.jbusres.2020.02.045.

17. C. Martella, A. Miraglia, J. Frost, M. Cattani, M. Steenc. Visualizing, clustering, and predicting the behavior of museum visitors, Pervasive and Mobile Computing 38, 430-443 (2017). DOI: 10.1016/j.pmcj.2016.08.011.

18. D. Kosmopoulos, G. Styliaras. A survey on developing personalized content services in museums, Pervasive and Mobile Computing 47, 54-77 (2018). DOI: 10.1016/j.pmcj.2018.05.002.

19. Y. Su, W. Teng. Contemplating museums' service failure: Extracting the service quality dimensions of museums from negative on-line reviews, Tourism Management 69, 214-222 (2018). DOI: 10.1016/j.tourman.2018.06.020.

20. S. Kemp. Design museum futures: Catalysts for education, Futures 94, $59-75$ (2017). DOI: $10.1016 /$ j.futures.2017.04.002.

21. C. Antón, C. Camarero, M.J. Garrido. A journey through the museum: Visit factors that prevent or further visitor satiation, Annals of Tourism Research 73, 48-61 (2018). DOI: 10.1016/j.annals.2018.08.002.

22. A. Absalyamova, T. Absalyamov, S. Absalyamova. Private Museums as a form of Preservation of Cultural Heritage, Procedia - Social and Behavioral Sciences 188, 218 221 (2015). DOI: 10.1016/j.sbspro.2015.03.376.

23. S. Ahmad, M. Y. Abbas, W. Z. Mohd, Y. Zafrullah. Museum Learning: Using Research as Best Practice in Creating Future Museum Exhibition, Procedia - Social and Behavioral Sciences 105, 370-382 (2013). DOI: 10.1016/j.sbspro.2013.11.039. 